\title{
A Study of Compost Added to a Casing Technique in Agaricus bisporus Cultivation from Phase III Bulk Compost
}

Diego Cunha Zied ${ }^{1}$ and Marli Teixeira Almeida Minhoni

Módulo de Cogumelos, Departamento de Produção Vegetal (Defesa Fitossanitária), Faculdade de Ciências Agronômicas, Universidade Estadual Paulista, Botucatu, Brazil

\section{J. Emilio Pardo-González}

Escuela Técnica Superior de Ingenieros Agrónomos, Universidad de Castilla-La Mancha, Campus Universitario, s/n 02071 Albacete, Spain

\section{Arturo Pardo-Giménez}

Centro de Investigación, Experimentación y Servicios del Champiñón (CIES), C/Peñicas, s/n, Apartado 63, 16220 Quintanar del Rey, Cuenca, Spain

\section{Additional index words. mushrooms industry, yield, earliness, technology process}

\begin{abstract}
The aim of this study was to assess the effect of the addition of different rates of colonized compost and formaldehyde treatment on production parameters (yield, biological efficiency, mushroom number, mushroom weight, and earliness) in a Dutch commercial casing using Phase III bulk compost as a base substrate for growing Agaricus bisporus. Four rates of spawn-run compost $\left(0 \mathrm{~g} \cdot \mathrm{m}^{-2}, 200 \mathrm{~g} \cdot \mathrm{m}^{-2}, 400 \mathrm{~g} \cdot \mathrm{m}^{-2}\right.$, and $\left.600 \mathrm{~g} \cdot \mathrm{m}^{-2}\right)$ and formaldehyde treatment (with or without) were used. The experiment was designed as a double factorial in a randomized complete block design. Each block contained six replicates per treatment (a compost bag with $20 \mathrm{~kg}$ ). The compost added to casing (CACing) technique when applied properly and combined with the use of Phase III compost had significant benefits, including increased mushroom yield, weight, and reduced the growing cycle, especially with the rate of $600 \mathrm{~g}$ of spawn-run compost $/ \mathrm{m}^{2}$ of casing. On the other hand, the application of formalin reduced yield with or without the CACing technique, which implies the need for an alternative treatment for disinfection. An alternative method may either be thermal or chemical treatments to the casing such as using formaldehyde before mixing the casing with spawn-run compost and before the addition of casing above the colonized compost.
\end{abstract}

The cultivation technology of Agaricus bisporus involves the following stages: preparation of the substrate (the compost), pasteurization of the compost, addition of fungal inoculums grown on cereal grains (the spawn) to the compost, and covering the compost surface after it has been fully colonized by the mushroom mycelium with a layer of soil or peat (the casing layer). Initial sporophores usually appear within 15 to $18 \mathrm{~d}$ after the casing and they are ready to harvest $\approx 7 \mathrm{~d}$ later (Nair and Hayes, 1975). The harvest phase varies between 4 and 6 weeks depending on

Received for publication 2 July 2010. Accepted for publication 23 Aug. 2010.

We thank the Coordenação de Aperfeiçoamento de Pessoal de Nível Superior (CAPES-No. 1184/ 09-1) for the scholarship granted for this work, the Graduate Program (Energia na Agricultura) in Faculdade de Ciências Agronômicas (FCA/UNESP, Brazil), the Consejería de Agricultura de Castilla-La Mancha (Spain), and the Diputación Provincial de Cuenca (Spain) for the financial support.

${ }^{1}$ To whom reprint requests should be addressed; e-maildczied@fca.unesp.br. the casing material and technology process used such as the compost added to casing (CACing) technique or the ruffling and scratching technique.

The CACing technique involves the application of small amounts of compost fully colonized (spawn-run compost) by the mushroom mycelium to the casing layer at casing time. The technique was developed in Ireland during the 1960s and reported for the first time in 1972 by MacCanna and Flanagan (1972). The CACing technique has several advantages, and the most important are: earlier first flush by 3 to $4 \mathrm{~d}$, more uniform distribution of mushrooms over the entire bed surface, and elimination of soil-breaking pins resulting in cleaner mushrooms (Samp, 1993; Vedder, 1989).

In the CACing technique, it is vital that the compost mixed into the casing layer is well run and disease-free (such as contaminations and viruses). As an alternative, commercial products are specifically inoculated for use in the casing to eliminate this risk factor although it is more expensive (Green, 1990; Miller et al., 1995). Other precautions to be followed are: 1) use the same spawn strain for the casing as for the compost; 2) avoid the use of compost that has been overheated; 3) remove pieces with black spots or that are excessively dry; 4) ensure exclusion of pests and diseases and discard material if it is positive for contaminations such as the presence of nematodes; and 5) exaggerate at all times the hygiene conditions (Tschierpe, 1999). In practice, amounts between $0.5 \mathrm{~kg} \cdot \mathrm{m}^{-2}$ and $2 \mathrm{~kg} \cdot \mathrm{m}^{-2}$ of slightly crushed spawn-run compost are used in growing areas (MacCanna, 1983; Vedder, 1989). A uniform distribution of material on the casing is vital for the success of the CACing technique (Tschierpe, 1999).

In Spain, the use of Phase III composting technology in bulk has been recently introduced. This technology provides final composts with relatively low moisture contents $( \pm 61 \%)$. To compensate for the low water in the compost, casing with high water-holding capacity that is based on peat is commonly used in Dutch commercial cultivation.

The casing materials may contain fungal spores, insect larvae, and nematodes. Therefore, before the use of these materials, they should be treated to limit their possible negative impact on mycelial growth and yield, which can be accomplished either by heat treatments or chemical treatments. Among the thermal treatments, the use of steam and forced air to pass through casing materials is the most widely used treatment although it is costly (Visscher, 1988). In places where the use of steam is too expensive or impractical, there is widespread use of volatile chemicals. Among these, formaldehyde has traditionally been the most widely used as a result of its broad spectrum of action.

Several advantages have been presented with the use of formaldehyde because the diffusion of chemical substances volatilize in the porous space of soil without changing its physical structure in quantities toxic to eliminate pests and competitors of $A$. bisporus (Pardo, 1999). This treatment has the benefit of being carried out before use or immediately after application of compost (Ferri, 1985; Vedder, 1978).

Therefore, this study was aimed to assess the effect of the addition of different rates of colonized compost and formaldehyde treatment on production parameters (yield, biological efficiency, mushroom number, mushroom weight, and earliness) in a Dutch commercial casing using Phase III bulk compost as a base substrate for growing A. bisporus.

\section{Materials and Methods}

Physical, chemical, and biological anal$y$ sis. To determine the physical, chemical, and biological characteristics of compost and casing layer, the following measurements were taken: moisture content (Mapa, 1994); pH (Aenor, 2001a; Ansorena, 1994); electrical conductivity (Aenor, 2001b); total nitrogen $(\mathrm{N})$ content (Foss, 2003); organic matter and ash (Ansorena, 1994; Mapa, 1994); carbon:nitrogen $(\mathrm{C}: \mathrm{N})$ ratio and crude fiber (Ankom, 2008); crude fat (Ankom, 2009); 
nitrogen-free extracts (González et al., 1987); cellulose, hemicellulose, lignin, and neutral detergent solubles (Ankom, 2005, 2006a, 2006b); particle real density (Aenor, 2001c); bulk density, total porosity, and water-holding capacity (Ansorena, 1994; Aenor, 2001c); carbonates and active lime (Mapa, 1994); pathogenic nematodes (Nombela and Bello, 1983); mites (Brady, 1969; Krantz, 1986); and competitor molds (Tello et al., 1991).

Compost. Colonized compost was obtained from a commercial company whose facilities were carried out in Phase III bulk. The development of compost occurred in the following stages: $6 \mathrm{~d}$ of pre-wetting straw (bundles maintained), $5 \mathrm{~d}$ of Phase I in bunker with forced air flow, $5 \mathrm{~d}$ in another bunker, and $2 \mathrm{~d}$ in a final bunker. In the end of Phase I, the compost was transferred to the pasteurization tunnel where Phase II was carried out for $8 \mathrm{~h}$ at $60{ }^{\circ} \mathrm{C}$ and $6 \mathrm{~d}$ at 45 to $50^{\circ} \mathrm{C}$. The compost was cooled and inoculated with the spawn; thereafter it was placed back in pasteurization tunnels for the mass incubation or spawn run (Phase III). Two tunnels of Phase III Bulk were done with three tunnels of Phase II.

Spawn. After Phase II of composting, the substrate was inoculated using Amycel Maxx mushroom mycelium, a commercial large offwhite hybrid strain that produces white mushrooms with smooth round caps and a solid dense tissue.
Casing. A mixture of peat neutralized with spent lime $\left(\mathrm{CaCO}_{3}\right)$ was used for the casing. The material originated in The Netherlands and marketed specifically for mushroom production. We refer to the material as Dutch commercial casing (DCC). Table 1 shows the physical, chemical, and biological characteristics of the material used.

Compost added to casing technique. The growing cycle was carried out using plastic bags with $\approx 20 \mathrm{~kg}$ of colonized compost. A casing layer with a thickness of $4 \mathrm{~cm}$ was applied over the compost. With this casing, compost slightly crushed and colonized was mixed with a dose of $200 \mathrm{~g} \cdot \mathrm{m}^{-2}, 400 \mathrm{~g} \cdot \mathrm{m}^{-2}$, or $600 \mathrm{~g} \cdot \mathrm{m}^{-2}$. The control was a treatment without compost added.

Formaldehyde treatment. Half of the bags used in this research were treated with formaldehyde (formalin; $18 \mathrm{~mL} \cdot \mathrm{m}^{-2}$ ) on the same day that the casing layers were added above the compost ( 37 d; Fig. 1). In this case, the remaining bags without formaldehyde were the controls.

Development of research. As shown in Figure 1, total cultivation time was $69 \mathrm{~d}$ with $18 \mathrm{~d}$ of Phase I, $7 \mathrm{~d}$ of Phase II, $12 \mathrm{~d}$ of Phase III, and $32 \mathrm{~d}$ of the harvest phase (with three flushes). The harvest phase was carried out in a controlled cultivation room using growth conditions recommended for the selected mushroom strain.

Table 1. Physical, chemical, and biological characteristics of compost and Dutch commercial casing.

\begin{tabular}{|c|c|c|c|}
\hline \multicolumn{2}{|l|}{ Compost } & \multicolumn{2}{|l|}{ Casing } \\
\hline Parameter & Value & Parameter & Value \\
\hline$\overline{\mathrm{pH}}(1: 5, \mathrm{p} / \mathrm{v})$ & 6.7 & $\mathrm{pH}(1: 5, \mathrm{v} / \mathrm{v})$ & 8.3 \\
\hline Moisture $\left(\mathrm{g} \cdot \mathrm{kg}^{-1}\right)$ & 616 & Moisture $\left(\mathrm{g} \cdot \mathrm{kg}^{-1}\right)$ & 759 \\
\hline Nitrogen $\left(\mathrm{g} \cdot \mathrm{kg}^{-1}\right)$ & 25.5 & Nitrogen $\left(\mathrm{g} \cdot \mathrm{kg}^{-1}\right)$ & 7.4 \\
\hline $\operatorname{Ash}\left(\mathrm{g} \cdot \mathrm{kg}^{-1}\right)$ & 281.2 & $\operatorname{Ash}\left(\mathrm{g} \cdot \mathrm{kg}^{-1}\right)$ & 388.2 \\
\hline Organic matter $\left(\mathrm{g} \cdot \mathrm{kg}^{-1}\right)$ & 718.8 & Organic matter $\left(\mathrm{g} \cdot \mathrm{kg}^{-1}\right)$ & 612.6 \\
\hline $\mathrm{C} / \mathrm{N}$ & 16.3 & Particle real density $\left(\mathrm{g} \cdot \mathrm{cm}^{-3}\right)$ & 0.848 \\
\hline Crude fiber $\left(\mathrm{g} \cdot \mathrm{kg}^{-1}\right)$ & 247.3 & Bulk density (fresh) $\left(\mathrm{g} \cdot \mathrm{cm}^{-3}\right)$ & 0.596 \\
\hline Crude fat $\left(\mathrm{g} \cdot \mathrm{kg}^{-1}\right)$ & 8.1 & Bulk density (dry) $\left(\mathrm{g} \cdot \mathrm{cm}^{-3}\right)$ & 0.144 \\
\hline Nitrogen-free extracts $\left(\mathrm{g} \cdot \mathrm{kg}^{-1}\right)$ & 304.0 & Total pore space $\left(\mathrm{mL} \cdot \mathrm{L}^{-1}\right)$ & 922 \\
\hline Hemicellulose $\left(\mathrm{g} \cdot \mathrm{kg}^{-1}\right)$ & 65.8 & Water-holding capacity $\left(\mathrm{kg} \cdot \mathrm{kg}^{-1}\right)$ & 4.55 \\
\hline Cellulose $\left(\mathrm{g} \cdot \mathrm{kg}^{-1}\right)$ & 213.0 & Total carbonates $\left(\mathrm{g} \cdot \mathrm{kg}^{-1}\right)$ & 196 \\
\hline $\operatorname{Lignin}\left(\mathrm{g} \cdot \mathrm{kg}^{-1}\right)$ & 158.0 & Active lime $\left(\mathrm{g} \cdot \mathrm{kg}^{-1}\right)$ & 60 \\
\hline Neutral detergent solubles $\left(\mathrm{g} \cdot \mathrm{kg}^{-1}\right)$ & 282.0 & Electrical conductivity $\left(\mu \mathrm{S} \cdot \mathrm{cm}^{-1}\right)$ & 224 \\
\hline Mites & Absence & Mites & Absence \\
\hline Nematodes & Absence & Nematodes & Absence \\
\hline Competitor moulds & Absence & Competitor moulds & Absence \\
\hline
\end{tabular}

Experimental design and analysis data. As mentioned earlier, the experiment was designed as a double factorial $(4 \times 2)$ in a randomized complete block design. Each block had six replicates per treatment (a compost bag with $20 \mathrm{~kg}$ ), four rates of spawn-run compost $\left(0 \mathrm{~g} \cdot \mathrm{m}^{-2}, 200 \mathrm{~g} \cdot \mathrm{m}^{-2}, 400 \mathrm{~g} \cdot \mathrm{m}^{-2}\right.$, and 600 $\mathrm{g} \cdot \mathrm{m}^{-2}$ ), and a formaldehyde treatment (with or without formalin). Statistical software (Sisvar, Federal University of Lavras, Brazil) was used for variance analysis. The means were separated using Tukey's test $(\leq 0.05)$ and analyzing all variables first and the distribution of production flush second for the different treatments. Finally, there was a linear correlation analysis between the variables analyzed and the respective treatments using the Sigma Stat 3.5 statistical software with a level of $P \leq 0.05$.

Variables analyzed. Mushrooms were harvested, counted, and weighed daily at their optimal commercial development stage (Hammond and Nichols, 1976). The harvested mushrooms were evaluated for their yield (fresh weight of mushroom divided by fresh weight of compost multiplied by 100 and expressed as percentages); biological efficiency, a practical estimate of the ability of mushrooms to convert substrate into fruiting bodies (fresh weight of mushroom divided by dry weight of compost multiplied by 100 and expressed as percentages); number of mushrooms per unit area harvested (basidiocarp count); unitary weight of mushroom (total fresh weight harvested during the crop divided by the number of mushrooms); and earliness (days to first harvest expressed as the number of days between casing and harvesting of the first flush).

\section{Results}

The addition of increasing amounts of colonized compost $\left(200 \mathrm{~g} \cdot \mathrm{m}^{-2}, 400 \mathrm{~g} \cdot \mathrm{m}^{-2}\right.$, and $600 \mathrm{~g} \cdot \mathrm{m}^{-2}$ ) in casing without formaldehyde treatment significantly increased levels of yield $(16.8 \%, 17.5 \%$, and $23.8 \%$, respectively) when compared with control casing $\left(0 \mathrm{~g} \cdot \mathrm{m}^{-2}\right)$. With formaldehyde treatments, yield increases of $7.7 \%, 13.7 \%$, and $20.3 \%$ were found for casing layers with $200 \mathrm{~g} \cdot \mathrm{m}^{-2}$, $400 \mathrm{~g} \cdot \mathrm{m}^{-2}$, and $600 \mathrm{~g} \cdot \mathrm{m}^{-2}$ of colonized compost, respectively, when compared with the control treatment (Table 2).

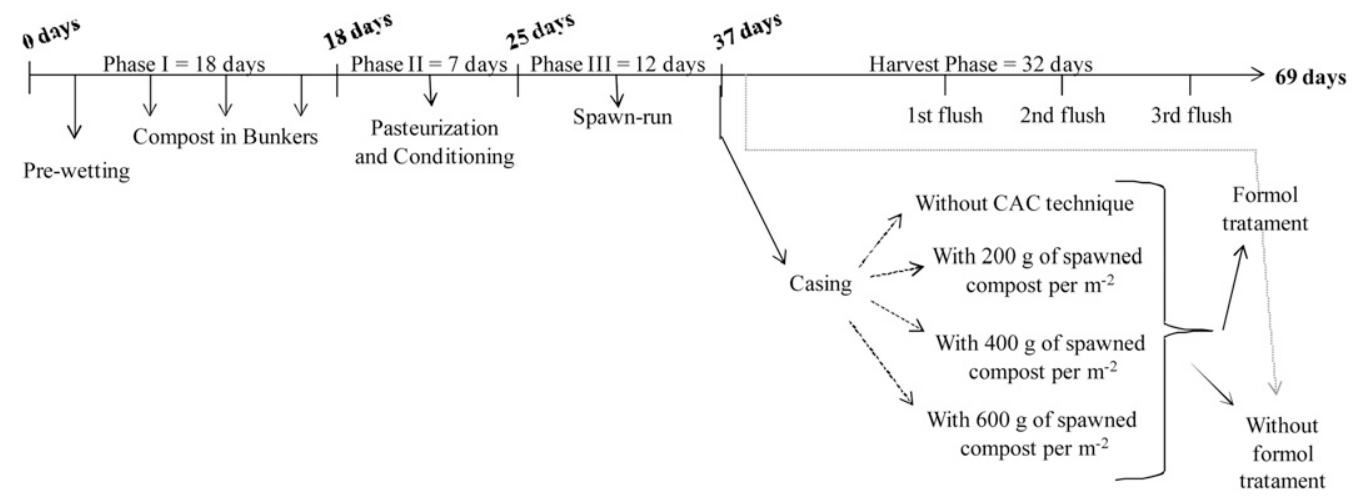

Fig. 1. Schedule of activities during the research with every step of production and its duration. 
The yield distribution by flush for the formaldehyde-treated casing (Fig. 2A) had a positive effect in all flushes with the CACing technique. In the first flush, all treatments had significant increases. In the second flush, the largest increase was found with the treatment at the highest dose $\left(600 \mathrm{~g} \cdot \mathrm{m}^{-2}\right)$, and the third flush had the largest increase with the lowest dose $\left(200 \mathrm{~g} \cdot \mathrm{m}^{-2}\right)$. In the casing that did not receive formaldehyde treatment, a significantly increased yield was evident only in the second flush, particularly with a dose of $200 \mathrm{~g} \cdot \mathrm{m}^{-2}$ (Fig. 2B)

The earliness of the crop in the first flush was between $1.6 \mathrm{~d}$ and $1.8 \mathrm{~d}$ for the CACing with formaldehyde treatment when compared with the control casing, and the earliness of the crop in the same flush for the untreated casing with formaldehyde treatment was between $1.7 \mathrm{~d}$ and $2.0 \mathrm{~d}$ (Fig. 2). These results indicated a positive effect of CACing on earliness, although this was not substantially affected by formaldehyde treatment.

The application of formalin after the addition of the casing layer had reductions in yield and biological efficiency for both the control (without CACing) and for the casing with spawn-run compost $\left(200 \mathrm{~g} \cdot \mathrm{m}^{-2}, 400 \mathrm{~g} \cdot \mathrm{m}^{-2}\right.$, and $600 \mathrm{~g} \cdot \mathrm{m}^{-2}$ ), demonstrating the important role that the microbiota of the spawn-run compost and DCC have on crop yields. Based on the biological efficiency, there were reductions of $9.3 \%, 6.1 \%, 11.9 \%$, and $12.3 \%$ for the casings with $0 \mathrm{~g} \cdot \mathrm{m}^{-2}, 200 \mathrm{~g} \cdot \mathrm{m}^{-2}, 400$ $\mathrm{g} \cdot \mathrm{m}^{-2}$, and $600 \mathrm{~g} \cdot \mathrm{m}^{-2}$ of colonized compost when compared the same casing without formaldehyde treatments.

In this study, the number of harvested mushrooms was the only parameter without significant differences (Tukey's test; $\leq 0.05$ ) indicating that both the CACing technique and formaldehyde treatments did not influence the number of fruiting bodies that develop during the growing period.

When a dose higher than $200 \mathrm{~g} \cdot \mathrm{m}^{-2}$ was used without formaldehyde treatment, significant relationships with the mushroom weight gain were observed. Comparing the effect of formaldehyde, only the rate of $400 \mathrm{~g} \cdot \mathrm{m}^{-2}$ had a difference with a $13.26 \%$ reduction based on the same rate without the formaldehyde treatment.

To demonstrate the effectiveness and impact of CACing technology in the growth of $A$. bisporus, an analysis was performed with the correlation results obtained for the yield, biological efficiency, mushroom number, and mushroom weight. No correlation was found at the level of significance $(P \leq$ 0.05 ) between the CACing technique and the mushroom number and the mushroom weight.
In contrast, the yield and biological efficiency had positive responses regarding the CACing technique (Fig. 3). The casing that received formaldehyde treatment showed a relatively strong correlation $(R=0.618)$ with the yield, whereas the untreated casing showed an even greater response to the CACing technique with a higher level of correlation $(R=$ $0.675)$. The same results were verified for biological efficiency values.

\section{Discussion}

With the modernization of industrial farming systems, some inconvenient or unexpected situations may appear (less moist compost, the need to adapt production to mechanical harvesting, and the development of new hybrid strains) producing deviations from the traditional crop system. Thus, making adjustments and finding solutions to these problems should be done quickly to produce the best product with the highest quality.

The CACing technique using DCC was evaluated in this study and resulted in significant increases in yield with values between $36.13 \%$ and $43.01 \%$ with $32 \mathrm{~d}$ of a harvest phase even when formaldehyde treatments were used. The yield increases resulting from the application of the CACing technique may be explained by the increased population of

Table 2. Data of mushrooms growing in the end of harvest phase (32 d after casing).

\begin{tabular}{|c|c|c|c|c|c|c|c|c|}
\hline \multirow{2}{*}{$\begin{array}{l}\text { CACing } \\
\text { (g compost } / \mathrm{m} \text { ) }\end{array}$} & \multicolumn{2}{|c|}{ Yield $(\%)$} & \multicolumn{2}{|c|}{ Biological efficiency (\%) } & \multicolumn{2}{|c|}{ Number of mushrooms (uni) } & \multicolumn{2}{|c|}{ Wt of mushroom $(\mathrm{g})$} \\
\hline & Formaldehyde & Control & Formaldehyde & Control & Formaldehyde & Control & Formaldehyde & Control \\
\hline 200 & $36.13 \mathrm{~A} \mathrm{a}$ & $38.51 \mathrm{~A} \mathrm{ab}$ & $94.52 \mathrm{~A} \mathrm{a}$ & $100.29 \mathrm{~A} \mathrm{ab}$ & $299.0 \mathrm{~A} \mathrm{a}$ & $329.1 \mathrm{~A} \mathrm{a}$ & $23.73 \mathrm{~A} \mathrm{a}$ & $24.06 \mathrm{~A} \mathrm{~b}$ \\
\hline 600 & $38.28 \mathrm{~B} \mathrm{a}$ & $43.01 \mathrm{~A} \mathrm{a}$ & $99.71 \mathrm{~B} \mathrm{a}$ & $112.01 \mathrm{~A} \mathrm{a}$ & $332.0 \mathrm{~A} \mathrm{a}$ & $324.8 \mathrm{~A} \mathrm{a}$ & $23.79 \mathrm{~A} \mathrm{a}$ & $25.89 \mathrm{~A} \mathrm{ab}$ \\
\hline \multirow[t]{2}{*}{ LSD } & \multicolumn{2}{|c|}{$3.77^{\mathrm{z}}$} & \multicolumn{2}{|c|}{$9.83^{z}$} & \multicolumn{2}{|c|}{$48.96^{z}$} & \multicolumn{2}{|c|}{$1.26^{z}$} \\
\hline & \multicolumn{2}{|c|}{$5.00^{\mathrm{y}}$} & \multicolumn{2}{|c|}{$13.04^{y}$} & \multicolumn{2}{|c|}{$64.95^{\mathrm{y}}$} & \multicolumn{2}{|c|}{$4.81^{y}$} \\
\hline
\end{tabular}

${ }^{z_{L S D}}=$ low significance difference of formol values.

${ }^{y}$ LSD $=$ low significance difference of CACing values.

Uppercase letters compare results in the same lines (formaldehyde values) within each variable analyzed. Lowercase letters compare results in the same columns (CACing values) within each variable and treatment analyzed.

CACing = compost added to casing; $\mathrm{CV}=$ coefficient of variation.
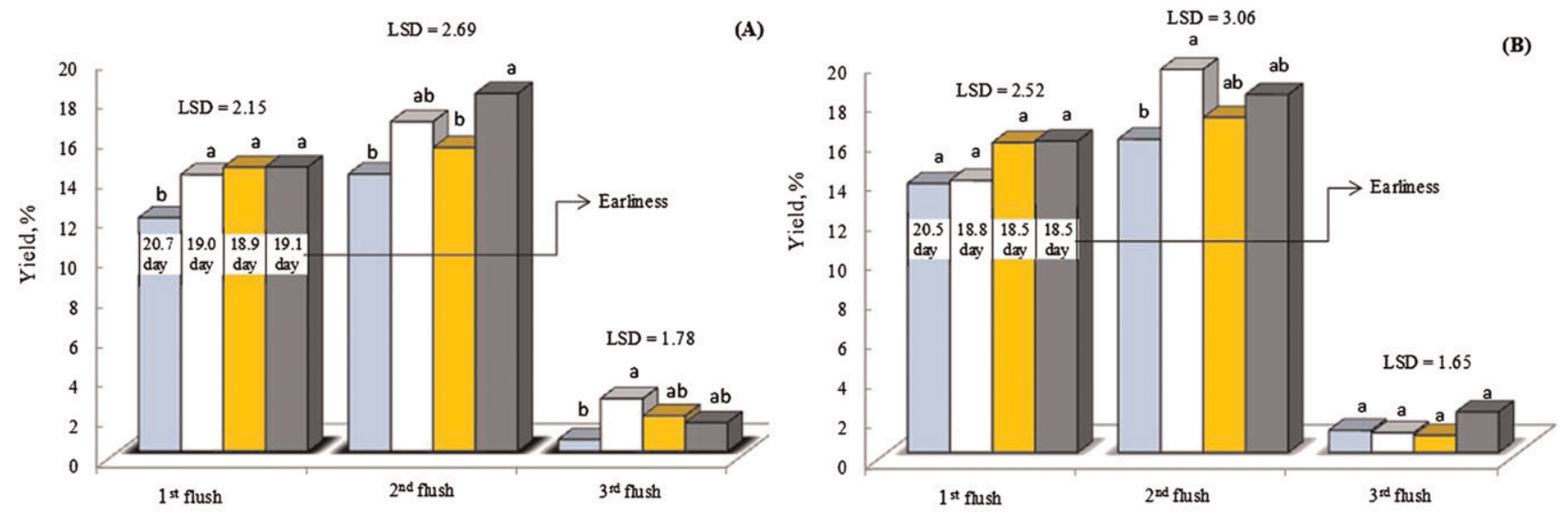

Fig. 2. Comparative yield during each flush of mushrooms and earliness values, in which $\mathbf{A}$ represents the data of formaldehyde treatment and $\mathbf{B}$ represents the data without formaldehyde treatment. Each column shows the results of control $[\square], 200 \mathrm{~g}[\square], 400 \mathrm{~g}[\square]$, and $600 \mathrm{~g}[\square]$ of compost added to casing $/ \mathrm{m}^{2}$. 

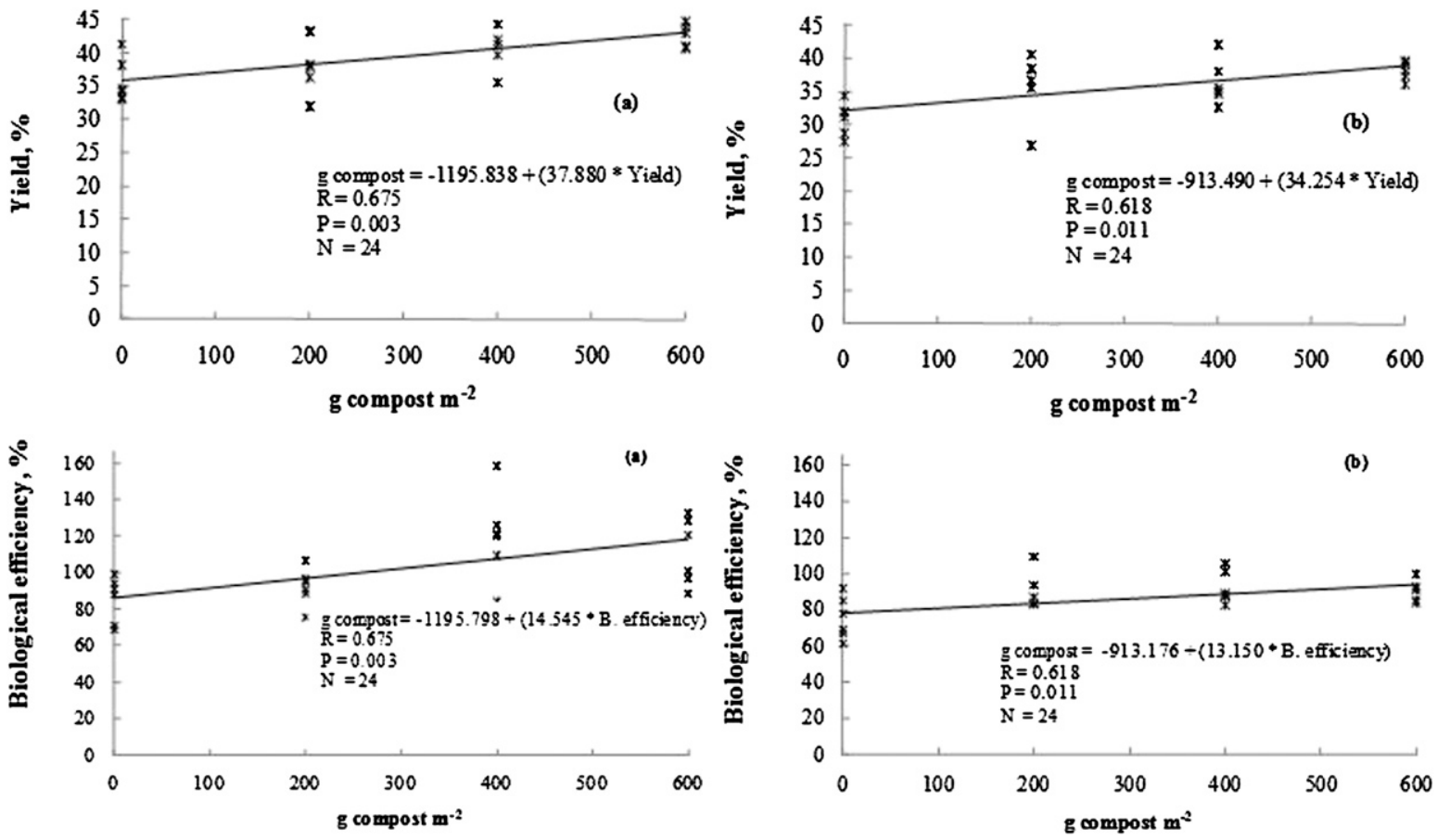

Fig. 3. Linear correlation between yield, biological efficiency, and the compost added to casing technique in which $\mathbf{A}$ indicates the values with formaldehyde treatment and $\mathbf{B}$ without formaldehyde treatment.

Pseudomonas and the increased aeration because of the addition of crushed colonized compost in casing layers from the application of this technique (Nair and Hayes, 1975). The biocide properties of formaldehyde may also explain the significantly reduced crop yields obtained in this study.

MacCanna and Flanagan (1972) used the same technique of spawn-run compost added to the peat and ground limestone at $125 \mathrm{~g}$, $250 \mathrm{~g}$, and $500 \mathrm{~g}$ per $6-\mathrm{kg}$ bag of compost, and they observed yield gains of $19 \%, 28 \%$, and $21 \%$, respectively. The same authors emphasize that certain amounts of spawn-run compost decreases yield while increasing production costs and problems of contamination, particularly viruses (MacCanna and Flanagan, 1972).

The use of high compost rates can appreciably change the physical and chemical characteristics of casings such as structure and electrical conductivity, which will affect their agronomic behavior. According to Amsing (1996), the presence of more mycelium raises the number of mushrooms to a maximal level followed by a reduction in the number of mushrooms if the mycelium is excessive resembling a parabolic function.

In the mushroom industry, the CACing technique is used because of its good results and several advantages such as the simplification of crop management, shorter production cycle, and individually spaced mushrooms on the surface (elimination of clumping), which facilitates the harvest in addition to producing a high-quality product (Tschierpe, 1999; Vedder, 1989). The results of our work verify that the number of mushrooms was unaffected by the CACing technique with regard to the arrangement of mushrooms (clumping characteristic). We found that DCC had good features and that no differences were detected after the addition of colonized compost.

Perusal of literature indicates that there is 3- to 5-d advancement as a result of the CACing technique (Nair and Hayes, 1975; Vedder, 1989). In our case, there was an advance of $\approx 2 \mathrm{~d}$ allowing the exclusion of the third flush given the low relative yield recorded. D'Hardemare and Talon (1980) observed that the CACing technique induces a different pattern of fruiting with a stronger and more uniform first flush that allows an easier harvest. This reduction in the production time (discarding the third flush) together with the use of Phase III Bulk compost may potentially double the production capacity of the growth chambers (harvest phase).

In Holland, it is normal practice to combine Phase III Bulk compost with the addition of $500 \mathrm{~g} \cdot \mathrm{m}^{-2}$ to $600 \mathrm{~g} \cdot \mathrm{m}^{-2}$ of CACing reducing the case run to $5 \mathrm{~d}$. This combination is ideal for large amounts of water added (nearly $50 \%$ of the total that will be necessary during all harvest phases) in the first $24 \mathrm{~h}$ to $26 \mathrm{~h}$ after casing addition above the compost (Green, 2004). This is the main advantage of CACing when compared with the ruffling and scratching technique. Scratching is done to break up the surface compaction and reduce the $\mathrm{CO}_{2}$ level, and ruffling the entire casing layer down to the compost surface is rotovated mechanically when the mycelium has developed approximately three-fourths into the casing layer (MacCanna, 1986).

Based on the obtained results, if the production is dedicated to fresh mushrooms, the CACing technique using $400 \mathrm{~g} \cdot \mathrm{m}^{-2}$ of colonized compost without formaldehyde treatment is a good alternative because it has good yield with large mushroom weights adding value to the product. If the final products are destined to industrialization (canning) of mushrooms, the dose of $600 \mathrm{~g} \cdot \mathrm{m}^{-2}$ of colonized compost without formaldehyde treatment is suggested because this process resulted in the highest yield and earliness.

\section{Conclusion}

We conclude that the compost added to casing (CACing) technique when applied properly and combined with the use of Phase III compost has significant benefits, including an increase in yield and weight of mushroom and the most important one is reduction in growing cycle. On the other hand, the application of formalin reduced yield with or without the CACing technique, which implies the need for an alternative treatment for disinfection. An alternative method may either be thermal or chemical treatments to the casing such as using formaldehyde before mixing the casing with spawn-run compost and before the addition of casing above the colonized compost.

\section{Literature Cited}

Aenor. 2001a. Mejoradores de suelos y sustratos de cultivo. Determinación del pH. Norma Española UNE-EN 13037. Asociación Española de Normalización y Certificación, Madrid, Spain.

Aenor. 2001b. Mejoradores de suelos y sustratos de cultivo. Determinación de la conductividad eléctrica. Norma Española UNE-EN 13038. Asociación Española de Normalización y Certificación, Madrid, Spain.

Aenor. 2001c. Mejoradores de suelos y sustratos de cultivo. Determinación de las propiedades físicas. Densidad aparente seca, volumen de aire, volumen de agua, valor de contracción y porosidad total. Norma Española UNE-EN 13041. Asociación Española de Normalización y Certificación, Madrid, Spain. 
Amsing, J.G.M. 1996. Effect of ruffling and CACing on mushroom production. De Champignoncultuur 40:25-33.

Ankom. 2005. Method for determining acid detergent lignin in beakers. Technology method AK 8/05. ANKOM Technology, Macedon.

Ankom. 2006a. Neutral detergent fiber in feeds. Filter bag technique. Technology Method 6. ANKOM Technology, Macedon.

Ankom. 2006b. Acid detergent fiber in feeds. Filter bag technique. Technology Method 5. ANKOM Technology, Macedon.

Ankom. 2008. Crude fiber analysis in feeds by filter bag technique. Technology method 7, AOCS Approved Procedure Ba 6a-05. Technology, Macedon.

Ankom. 2009. Rapid determination of oil/fat utilizing high temperature solvent extraction. ANKOM technology method 2, AOCS Official Procedure Am 5-04. ANKOM Technology, Macedon.

Ansorena, J. 1994. Sustratos. Propiedades y caracterización. Mundi-Prensa, Madrid, Spain.

Brady, J. 1969. Some physical gradients set up in Tullgren funnels during the extraction of mites from poultry litter. J. Appl. Ecol. 6:391-402.

D'Hardemare, G. and J.L. Talon. 1980. From casing to fruiting. Mushroom J. 92:299-300.

Ferri, F. 1985. Coltivazione. Agaricus bisporus (Lange) Imbach. Terra di coperura e ricoprimento, p. 206-210. In: Fungi, I. (ed.). Micologia, isolamento, coltivazione. Edagricole, Bologna, Italy.

Foss. 2003. The determination of nitrogen according to Kjeldahl using block digestion and steam distillation. Foss Application Note AN 300, Höganäs.

González, J., P. Alvira, and G. González. 1987. La cascarilla de arroz en la alimentación animal. II. Composición químico-bromatológica. Rev Agroquím Tecnol Aliment 27:139-149.

Green, R. 1990. Casing spawn-A new development? Mushroom J. 216:445-446.

Green, R. 2004. Modern CI and casing techniques. Mushroom J. 657:6-9.

Hammond, J.B.W. and R. Nichols. 1976. Carbohydrate metabolism in Agaricus bisporus (Lange) Sing.: Changes in soluble carbohydrate during growth of mycelium and sporophore. J. Gen. Microbiol. 93:309-320.

Krantz, G.W. 1986. A manual of acarology. 2nd Ed. Oregon State University Book Stores, Corvallis, OR.

MacCanna, C. 1983. Spawned casing. Mushroom J. 129:329-333.

MacCanna, C. 1986. Casing, p. 131-138. In: Commercial mushroom production. An Foras Taluntais, Dublin, UK.

MacCanna, C. and J.B. Flanagan. 1972. Casing types and techniques. Mushroom Sci. 3:727731.

Mapa. 1994. Métodos oficiales de análisis. Tomo III. Servicio de Publicaciones del Ministerio de Agricultura, Pesca y Alimentación, Madrid, Spain.

Miller, M.W., H.M. Versagli, and C.E. Smith. 1995. A summary of the evolution and development of commercial casing inoculums. Mushroom News 43:16-19.
Nair, N.G. and W.A. Hayes. 1975. Some effects of casing soil amendments on mushroom cropping. Aust. J. Agr. Res. 26:181-188.

Nombela, G. and A. Bello. 1983. Modificaciones al método de extracción de nematodos fitoparásitos por centrifugación en azúcar. Bol. Sanid. Veg., Plagas 9:183-189.

Pardo, A. 1999. Respuestas agronómicas de diferentes materiales de cobertura para el cultivo del champiñón, Agaricus bisporus (Lange) Imbach. Diss., Universidad de Castilla-La Mancha.

Samp, R. 1993. Developments in spawned casing. Mushroom J. 523:14-15.

Tello, J., F. Vares, and A. Lacasa. 1991. Selección y tratamiento de muestras. Análisis de muestras. Observación microscópica, p. 29-77. In: Manual de laboratorio. Diagnóstico de hongos, bacterias y nematodos fitopatógenos. Ministerio de Agricultura, Pesca y Alimentación, Dirección General de Sanidad de la Producción Agraria, Madrid, Spain.

Tschierpe, H. 1999. CACing-The elegant method to influence crop rhythm. AMGA Journal Spring:14-18.

Vedder, P.J.C. 1978. Tierra de cobertura y cobertura, p. 235-254. In: Mundi-Prensa, S.A. (ed.). Cultivo moderno del champiñón. Mundi-Prensa, Madrid, Spain.

Vedder, P.J.C. 1989. Practical experience with the CAC'ing technique. Mushroom Sci. 8:381-385.

Visscher, H.R. 1988. Casing soil, p. 73-89. In: van Griensven, L.J.L.D. (ed.). The cultivation of mushrooms. East Grinstead, Sussex, UK. 